\title{
NOVIDADES DA BACIA DO PRATA: ARQUEOLOGIA E HISTÓRIA INDÍGENA DA PROVÍNCIA DE ENTRE RÍOS, ARGENTINA
}

RAFAEL GUEDES MILHEIRA ${ }^{1}$

UFPel

\section{RESENHA}

BONOMO, Mariano. Historia Prehispánica de Entre Ríos. Buenos Aires: Fundación de Historia Natural Félix de Azara/Universidad Maimónides, 2012. 90 p.

Historia Prehispánica de Entre Ríos, livro publicado por Mariano Bonomo, através da Fundación de Historia Natural Félix de Azara, Universidad Maimónides, no ano de 2012, é um livro que busca a divulgação do conhecimento arqueológico oriundo das pesquisas realizadas desde o final do século XIX na Província de Entre Ríos, Argentina. O livro tem três objetivos centrais: 1) apontar, através de informações arqueológicas, a profundidade histórica e a complexidade multicultural das ocupações humanas no território entrerriense; 2)

\footnotetext{
1 Professor do Bacharelado em Antropologia/Arqueologia e do Programa de Pós-graduação em Antropologia da Universidade Federal de Pelotas. Professor do Programa de Pós-graduação em Patrimônio cultural da Universidade Federal de Santa Maria. Coordenador do Laboratório de Ensino e Pesquisa em Antropologia e Arqueologia (LEPAARQ-UFPEL). E-mail: milheirarafael@gmail.com .
} 
demonstrar o protagonismo das populações ameríndias, que manejaram os recursos ambientais e constituíram sociedades complexas, ao contrário do proposto pela Arqueologia e Antropologia tradicionais; 3) reforçar a importância da Arqueologia enquanto disciplina com potência para criticar e rediscutir a história tradicional (esta, por sua vez, comumente embasada na documentação escrita), contribuindo para a construção da memória social contemporânea.

Bonomo ressalta, ao longo do livro, a relevância da história milenar do território que, hoje, abarca a Província de Entre Ríos. Essa história é fortemente entrelaçada ao passado das terras baixas da América do Sul, além de estar integrada à bacia hidrográfica do Rio da Prata e à bacia amazônica, ambientes que, no passado, eram unidos por cursos de águas navegáveis.

Assim, o autor debruça-se, no primeiro capítulo do livro, sobre as modificações desse ambiente ao longo do tempo, e seus recursos orgânicos e inorgânicos, descrevendo o cenário da história não ocidental. Esses cursos de águas navegáveis teriam sido norteados por extensas vias de comunicação fluvial, permitindo o fluxo de pessoas e ideias entre esses distintos ambientes, explicando, nesse sentido, a ampla dispersão geográfica que possuem as famílias linguísticas Caribe, Arawak e Tupi-Guarani.

O autor propõe uma narrativa conexionista, que demonstra a articulação cultural dos grupos indígenas entre diferentes bacias hidrográficas. Além disso, busca um diálogo bastante profícuo entre a Arqueologia produzida por grupos de pesquisadores contemporâneos e os pesquisadores do passado. É interessante como Bonomo não se furta em referenciar e debater os autores desde o século XIX, como Ramón Lista e Juan Bautista Ambrosetti, Felix Outes e Luís María Torres, Antonio Serrano, Eduardo Cigliano e María Amanda Caggiano, os quais, em seu tempo, principiaram os estudos arqueológicos na Província de Entre Ríos e de outras localidades, deixando um legado intelectual criticável, como não poderia deixar de ser, mas muito coerente do ponto de vista científico, pelo seu grande potencial de interlocução.

A relação entre fontes é outra abordagem que chama atenção na obra do autor. Para compreender o panorama histórico das diferentes culturas indígenas que habitaram os rios Paraná, Uruguai e da bacia do 
Prata, Bonomo vale-se do confronto de dados arqueológicos, etnográficos e etno-históricos. Por um lado, o autor não se limita ao descritivismo arqueológico, vulgarmente chamado de "arqueologuês", cuja linguagem, muitas vezes, torna-se uma barreira para o entendimento das obras por não iniciados na Arqueologia. Por outro lado, contribui para a construção de um conhecimento histórico de longa duração, que não é uma visão míope gerada apenas pela leitura das fontes históricas colonialistas (limitadas pelo tempo e pelas ideologias de quem as escreveu); tampouco prende-se aos inventários materiais das coleções arqueológicas.

Partindo aos dados arqueológicos e aos modelos interpretativos, o autor inicia sua narrativa tratando da ocupação regional por uma perspectiva cronológica. Ele apresenta as ocupações relativas aos grupos afiliados historicamente aos Chaná-timbu e aos Guarani, cujas ocupações em ilhas e às margens de cursos menores do rio Paraná ocorreram entre os anos 600 e 1492 AD. Os lugares ocupados por esses grupos foram albardões naturais e montículos artificiais de terra com dimensões que atingem até pouco mais de dois metros de altura.

A alta frequência de artefatos de uso cotidiano, como instrumentos feitos de cerâmicas (pratos, colheres de cerâmica, panelas, jarras, contas de colar e cachimbos) permite interpretar que os montículos de terra eram usados como áreas residenciais, sendo pequenas aldeias. Bonomo salienta, ainda, o primor estilístico e tecnológico das vasilhas cerâmicas, que apresentam apliques, pinturas, decorações plásticas variadas e, até mesmo, apêndices zoomórficos. A presença desses apliques na cerâmica foi atribuída à cultura dos Ribeirinhos plásticos, que ocorrem em uma ampla área ao longo do rio Paraná, porém, com maior frequência no seu delta superior e no médio curso, ocorrendo desde o início da era cristã até a chegada dos europeus.

Os apêndices, em sua maioria representativos de animais com plumas, remetem a um complexo simbólico que abrange distintos grupos da Amazônia, Chaco, Mato Grosso e Guianas. Além disso, a alta frequência de sepultamentos humanos no interior desses montículos primários, secundários e de elementos ósseos dispersos - também sugere que esses sítios arqueológicos tenham sido usados como 
cemitérios, não havendo, portanto, separação espacial entre os vivos e os mortos. As diferentes formas de enterramento, associadas aos conjuntos funerários que envolvem restos de animais e materiais de regiões, muitas vezes, longínquas, indicam relações assimétricas que envolvem diferenças de lideranças, posição e prestígio social.

No rio Uruguai, por sua vez, estão as ocupações mais antigas, que alcançam a escala cronológica de até 11 mil anos AP., relativas a grupos de caçadores-coletores. O material diagnóstico de sua ocupação é chamado de ponta de projétil rabo de peixe (cola de pescado). Foram grupos humanos que ocuparam diferentes sítios arqueológicos, como concheiros e acampamentos residenciais e oficinas líticas. Essas ocupações das planícies aluviais dos rios Paraná e Uruguai contrastam com as planícies interioranas, onde poucos são os achados arqueológicos. Isso aponta para uma menor densidade demográfica em tempos pré-coloniais, mas que pode ser o resultado de uma menor quantidade de pesquisas. São assentamentos menores, relativos a grupos de caçadores-coletores, cuja subsistência foi baseada na caça de animais de médio e pequeno porte, assim como na coleta de raízes.

As populações guarani tiveram sua ocupação em uma ampla faixa territorial, que vai da Amazônia até as ilhas Martin Garcia e Punta Lara, no rio da Prata. A chegada dos Guarani nessa porção meridional foi representada por sítios arqueológicos compostos por manchas de terra preta e por cerâmicas com decorações plásticas e polícromas. A presença Guarani na região causou uma série de mudanças culturais, de reacomodações territoriais e de novas formas de relações sociais com as populações locais. É possível perceber, também, que a expansão territorial guarani foi diferenciada regionalmente, visto que, nas zonas com ocupação dos grupos Chaná-timbú, há uma menor quantidade de elementos materiais de origem guarani.

Transformações sociais em larga escala ocorreram também com a chegada das populações europeias na bacia do rio da Prata, intensificadas a partir de 1536, com a chegada de mais de uma frota, formada por mais de 2500 homens e mulheres. Em mapas de primeira mão, os dados históricos apontam a presença de diferentes grupos culturais, pertencentes a uma mesma etnia, habitando a bacia do Prata e que foram, em sua grande maioria, exterminados pelas doenças e 
guerras, sendo nomeados de: Chaná-timbú, Corondá, Quiloazas, Caracarais, Chaná, Mbeguá, Chaná-mbeguá, Timbú, Mocoretás, Guaranis, Charrúas e Querandí.

No último capítulo, "el pasado presente", o autor chama atenção para o fato de que sítios arqueológicos vêm sendo impactados e destruídos por pesquisas de amadores e pelo uso contemporâneo e inadequado dos espaços arqueológicos (exploração irregular de terra preta, uso dos montículos para construção de moradias, abertura de hortas, etc.). Embora exista uma legislação de proteção aos sítios arqueológicos, essas ações irregulares perduram devido à ausência de projetos de divulgação e colaboração científica.

O livro trata de uma história cheia de detalhes, destrinchada em uma rica narrativa. Assim, o autor descreve um amplo território, de muitas culturas, que perduraram no tempo, mas que foram caladas pela historiografia tradicional por conta dos interesses ideológicos do estado nacional argentino, uma postura nacionalista que se repete em todos os países latino-americanos, onde os indígenas foram silenciados em prol da modernização, do branqueamento étnico, do progresso e da formação de identidades nacionais euroreferenciadas. Nesse sentido, a obra de Mariano Bonomo pode ser vista como uma narrativa que busca criticar a história oficial, tradicional e maniqueísta, demonstrando o potencial da Arqueologia como uma ciência que contribui para o conhecimento das histórias de longa duração, detectáveis, apenas, através do estudo da cultura material.

\section{Referência bibliográfica}

BONOMO, Mariano. Historia Prehispánica de Entre Ríos. Buenos Aires: Fundación de Historia Natural Félix de Azara/Universidad Maimónides, 2012. 